\title{
UJI COBA PENGOPERASIAN JARING UDANG CIKER DI PERAIRAN KAIMANA PROVINSI PAPUA BARAT
}

\author{
Misbah Sururi, Abu D Razak, Mustasim, Amir Suruwaky, Samsul Muhammad \\ Politeknik Kelautan dan Perikanan Sorong, Papua Barat. \\ Korespondensi: misbahsururi.apsor@gmail.com
}

\begin{abstract}
Abstrak
Penelitian bertujuan mengetahui apakah gillnet $P A$ monofilament yang dioperasikan secara aktif (ciker) sebagai alat tangkap udang introduksi memiliki kinerja yang lebih baik dibandingkan dengan pengoperasian secara pasif. Ujicoba ciker dilakukan dengan experimental fishing selama 9 kali ulangan yang berlangsung pada bulan November tahun 2017 di Perairan Kabupaten Kaimana. Data dianalisa secara diskriptif dengan persamaan efektifitas, dan low impact by-catch, selanjutnya dilakukan uji kenormalan dan dilanjutkan uji beda (uji t dan f) dengan selang kepercayaan 95\%. Hasil penelitian menunjukkan bahwa pengoperasian jaring sistim aktif (ciker) mendapatkan hasil tangkapan udang sebanyak $125.41 \mathrm{~kg}$ (ratarata $13.93 \mathrm{~kg}$ ), sehingga lebih efektif dibandingkan dengan sistim pasif sebanyak $53.72 \mathrm{~kg}$ (rata-rata $5.96 \mathrm{~kg}$ ), tetapi jaring aktif ciker juga mendapatkan by-catch yang lebih tinggi dibandingkan dengan jaring pasif. Jumlah by-catch pada jaring aktif dan pasif yaitu masing-masing $298,57 \mathrm{~kg}$ dan $174.31 \mathrm{~kg}$, sehingga direkomendasikan untuk melakukan kajian atau rekayasa alat tangkap jaring udang PA monofilament khususnya untuk tujuan mengurangi by-catch.
\end{abstract}

Kata Kunci : Udang penaeid, efektifitas, low impact, ciker, Kaimana.

\section{GILLNET OPERATION WITH ACTIVE FISHING METHOD (CIKER) IN KAIMANA WATERS, WEST PAPUA PROVINCE}

\begin{abstract}
This research aims to find out if PA monofilament gillnet with active fishing method (ciker) has better performance compared to passive method. This reserach was performed by experimental fishing with 9 repetition on November 2017 in the waters of Kaimana regency. Data were analyzed by using statistical methods ( normality test, t-test and f-test with confidence interval of 95\%), effectiveness index formula, low-impact by-catch analysis. The result showed that gillnet with active method (ciker) got higher shrimp catch $(125,41 \mathrm{~kg}$ with average catch by $13,93 \mathrm{~kg}$ ) compared to passive method $(53,72 \mathrm{~kg}$ with average catch by $5,96 \mathrm{~kg})$, which is significantly differ with $\mathrm{F}$-cal $=4>\mathrm{F}$-tab $(0.05,8)=3,4 ;$ and $\mathrm{t}$-cal $=5,39$ $>\mathrm{t}-\operatorname{tab}(0.05,8)=2,3$. However, gillnet with active fishing method (ciker) also has higher by-catch $(298,57 \mathrm{~kg})$ compared to passive method $(174,31 \mathrm{~kg})$, which is significantly differ with $\mathrm{F}$-cal $=4,07>\mathrm{F}$-tab $(0.05,8)=3,4$; and $\mathrm{t}$-cal $=4,35>\mathrm{t}$ $\operatorname{tab}(0.05,8)=2,3$. The result of effectiveness index formula showed that active fishing method (ciker) has higher effectiveness index $(1,74)$ compared to passive method $(0,74)$, while low-impact by-catch analysis showed that both fishing method has high impact (more than 50\%). Therefore, the reseach related to gillnet engineering to reduce by-catch is highly recommended to be performed.
\end{abstract}

Key Word : penaeid shrimp, effectivenes, low impact, ciker, Kaimana.

\section{PENDAHULUAN}

Pemanfaatan sumberdaya udang di perairan Arafura sudah berlangsung cukup lama dan status pemanfaatannya sudah berada dalam tahapan yang lebih tangkap (Sumiono, 2012; Suman, A \& F. Satria, 2014; WWF, 2015). Selanjutnya Suman, A \& F. Satria, 2014, menjelaskan bahwa berbagai upaya pengelolaan penangkapan udang di Arafura telah diupayakan, dengan dikeluarkan beberapa regulasi yaitu: Keppres No. 39/1980; Kepmentan No. 930/Kpts/ Um/12/1982;SK Ditjen Perikanan No. IK. 010/S3.8075/82K; SK Ditjen Perikanan No. IK.010/S3.8063/82K; Kepress No 85 tahun 1982; Kepmentan No. 816/ Kpts/ Ik.120/11/90; UU no 13 / 2004 No. 3; Permen KP No. PER. 05 /MEN/2008 pasal 74; dan SK Ditjen Perikanan Tangkap No. 08/DJ-PT/2010 direvisi menjadi SK Ditjen PT. No. 38/DJPT-2010. Regulasi tersebut dipandang belum mampu memberikan solusi dalam pengelolaan perikanan udang yang ramah lingkungan, sehingga pada Tahun 2014 pemerintah menerbitkan regulasi yang banyak menimbulkan pro dan kontra yaitu Peraturan Menteri Kelautan dan Perikanan Nomor 56
Tahun 2014 tentang "penghentian sementara (moratorium) perizinan usaha perikanan tangkap di wilayah pengelolaan perikanan negara republik Indonesia. Satu tahun berikutnya disusul dengan Permen KP Nomor 02 Tahun 2015 yaitu tentang Pelarangan Penangkapan ikan dengan Pukat Hela dan Pukat Tarik. Sejak dikeluarkanya regulasi tersebut, maka tidak ada lagi penangkapan udang penaeid menggunakan alat tangkap pukat udang di seluruh WPP-RI, khususnya di Perairan Kaimana.

Berbagai upaya terus dilakukan dalam rangka mencari solusi alat tangkap alternatif udang penaeid. Salah satunya adalah kegiatan Dirjen Tangkap dalam forum RYBIC II yang terus mengumpulkan berbagai informasi penangkapan udang serta melakukan sharing dengan berbagai ahli dalam mencari solusi alat tangkap alternatif pengganti trawl untuk menangkap udang penaeid. Salah satu rekomendasinya yaitu menggunakan gillnet dengan pengoperasian secara aktif atau yang disebut dengan "ciker".

Penangkapan udang menggunakan trammel net di Perairan Kaimana Tahun 2017 rata-rata mempunyai daya tangkap by-catch yang lebih tinggi 
dibandingkan dengan jaring udang PA monofilament. Hal ini dikarenakan kontruksinya yang terdiri dari tiga lapis membuat ikan terbelit, sementara hasil analisa efektivitas menunjukkan bahwa kedua alat tangkap rata-rata cukup efektif untuk menangkap udang ((Misbah dkk, 2017). Hasil wawancara menyatakan bahwa banyaknya hasil tangkapan sampingan sangat berhubungan dengan musim penangkapan yang ada. Pada saat musim udang melimpah, maka by-catch yang didapatkan di jaring sedikit, dan sebaliknya by-catch akan banyak ketika udang yang terdapat di kolom air terbatas (Misbah dkk, 2017). Sehubungan dengan pelaksanaan ujicoba ciker dilakukan tidak pada musim puncak, maka diputuskan ujicoba ciker menggunakan jaring udang $P A$ monofilament yang biasa dioperasikan oleh masyarakat ketika belum musim puncak udang dengan harapan agar by-catch yang tertangkap lebih sedikit.

Tujuan Penelitian ini adalah untuk mengetahui kinerja hasil ujicoba kinerja alat tangkap introduksi (ciker) di Perairan Kaimana sehingga dapat sebagai bahan informasi awal pengembangan metode penangkapan udang penaeid menggunakan sistim ciker / bottom encircling gillnet sehingga dapat digunakan sebagai bahan acuan dalam penyempurnaan alat tangkap alternatif penangkapan udang penaeid.

\section{METODE PENELITIAN}

Penelitian berlangsung pada bulan November tahun 2017 di Perairan Kabupaten Kaimana, Provinsi Papua Barat. Ujicoba ciker dilakukan dengan metode experimental fishing selama 9 kali ulangan, setiap perlakukan menggunakan jaring udang $P A$ monofilament 4 piece $(426 \mathrm{~cm}$ x $22 \mathrm{~cm}$, mesh size 1,75 inch). Pengujian dilakukan pada waktu yang sama masing-masing selama sekitar 1 sampai 1.5 jam didalam perairan, menggunakan satu longboat dengan sistim pengoperasian jaring pasif disetting pertama, kemudian longboat melakukan pengoperasian jaring aktif dengan jarak sekitar 500 meter, dengan asumsi pengoperasian aktif sudah tidak mempengaruhi lokasi jaring pasif dan kondisi perairan diasumsikan homogen. Jaring aktif diputar dengan melawan arus dengan kecepatan yang rendah karena jaring monofilament sangat tipis dan dikhawatirkan rusak, sehingga selama 1.5 jam hanya melingkar 2 (dua) kali putaran. Pada hari berikutnya dilakukan pergantian lokasi jaring pasif di lokasi aktif dan sebaliknya. Waktu pengambilan data satu kali pada pagi hari (05.30 - 07.00 dan satu kali pada sore hari $18.30-20.00$, penentuan waktu perendaman jaring dan waktu pagi dan sore hari diputuskan berdasarkan hasil wawancara dengan nelayan sesuai pengalaman yaitu merupakan waktu terbaik untuk pengoperasian alat tangkap udang di Tawera, Kabupaten Kaimana. Lokasi Penelitian ditampilkan pada Gambar 1.

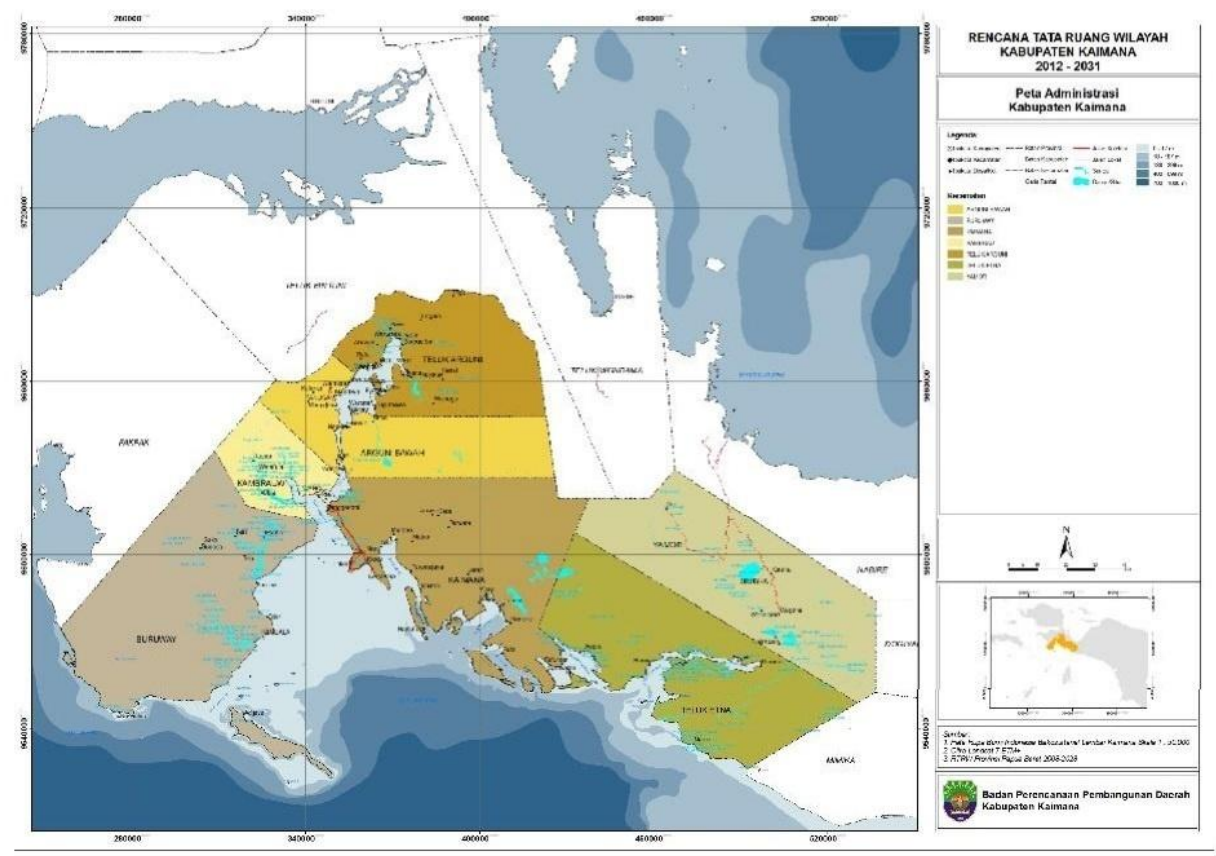

Gambar 1. Peta Lokasi Penelitian (Diolah dari Lampiran BPS 2016)

Data dianalisa secara diskriptif dengan persamaan efektivitas sederhana dan low impact by-catch ( Jhon, 1986) sebagai berikut :

1) Efektivitas Penangkapan

$$
\text { Efektivitas }=\frac{\text { Output } \text { Aktual }}{\text { Output Target }}
$$

Dengan kriteria : Apabila $E \geq 1$, dikategorikan efektif dan Apabila $E<1$, dikategorikan tidak efektif. 
2) Low impact by-cath

Presentase By-Catch $(P b c)$

$$
=\frac{\text { By catch }}{\text { Hasil Utama }} \times 100 \%
$$

Dengan kriteria ; $\mathrm{Pbc}<20 \%$, low impact $; 20$ $\%<\mathrm{Pbc}<50 \%$, middle impact; $\mathrm{Pbc}>50 \%$, high impact

3) Untuk mengetahui alat tangkap mana yang terbaik kinerjanya dilakukan uji kenormalan dan dilanjutkan dengan uji coba (uji t dan f) dengan selang kepercayaan $95 \%$ dengan software minitab.

\section{HASIIL DAN PEMBAHASAN}

\section{Deskripsi Jaring Udang PA Monofilament}

Jaring udang $P A$ monofilament termasuk dalam alat tangkap gillnet, yaitu alat tangkap berbentuk lembaran jaring persegi panjang yang menangkap ikan sasaran dengan menghadang ruaya ikan (Emanuel, 2010; Iporenu dkk, 2013). Alat ini biasa digunakan oleh nelayan lokal dengan daerah pengoperasian pada perairan muara sungai dan pingggiran pantai di Sekitar Perairan Arguni sampai Tawera. Biasanya nelayan mengoperasikan alat ini pada perairan yang cukup dangkal, berkisar 1 - 2 meter, dan paling dalam hanya 5 meter. Dalam pengoperasiannya, nelayan sering turun ke air untuk membenarkan posisi jaring serta melepas hasil tangkapan. Pengoperasian jaring udang oleh nelayan Tawera disajikan pada Gambar 2.

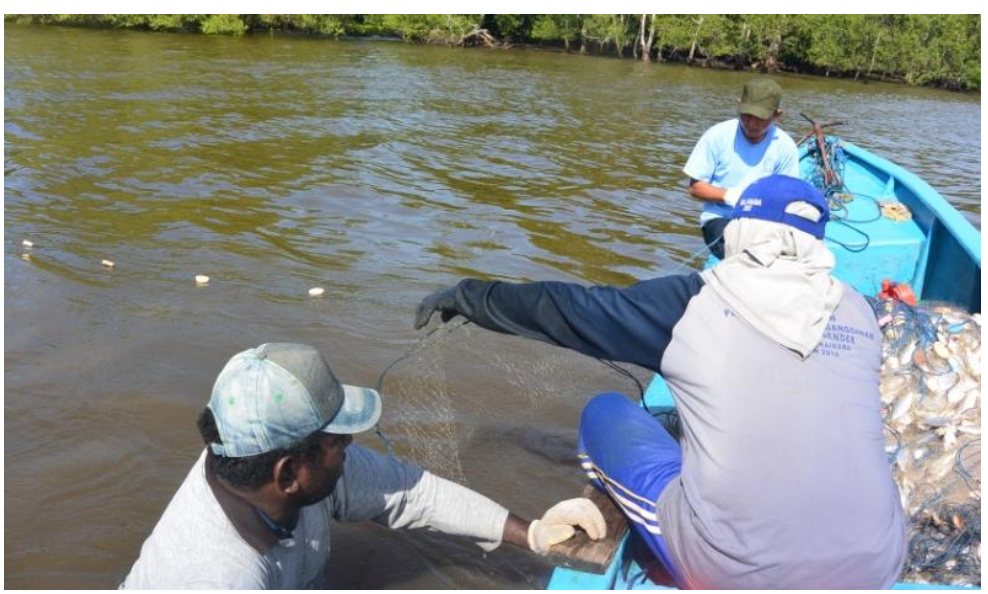

Gambar 2. Pengoperasian Jaring udang PA monofilamet

Jaring udang PA monofilament memiliki konstruksi seperti gillnet pada umumnya, yaitu terdiri dari pelampung, tali pelampung dan tali ris atas, lembaran jaring satu lapis, tali ris bawah dan pemberat (Martasuganda 2008 dan Puspito 2009) Jaring ini tidak memiliki srampat (selvadge) sebagai penguat jaring seperti yang terdapat pada alat trammel net. Karakteristik utama dari jaring udang adalah ukuran benang yang dipakai sangat kecil, halus, licin dengan mesh size kecil (1,75" dan 2") dan shortening besar, sehingga udang dan ikan sangat mudah terjerat oleh jaring. Konstruksi dan desain udang ditampilkan pada Tabel 1 dan Gambar 3.

Tabel 1. Konstruksi Jaring udang PA Monofilament di Kaimana

\begin{tabular}{ll}
\hline Bagian konstruksi Jaring & \multicolumn{1}{c}{ Spesifikasi } \\
\hline Tal ris atas (upper line) & Poly Ethylene, panjang 42,16 m, diameter 3 mm, pilinan Z \\
Tali pelampung (bouy line) & Poly Ethylene, panjang 42,16 m,diameter $3 \mathrm{~mm}$, pilinan Z \\
Pelampung (bouy) & Karet sandal, bulat, panjang $19 \mathrm{~mm}$, jarak $62 \mathrm{~cm}$, jumlah \\
& 69 buah \\
Jaring (netting) & PA Monofilament, nomor 20, mesh size $50 \mathrm{~mm}$, jumlah \\
& mata horizontal 1496, verikal 70 mata, shortening atas \\
& 0,56 dan bawah 0,62. \\
Pemberat (sinker) & Timah (Pb), oval, panjang $16 \mathrm{~mm}$, jumlah $143 \mathrm{buah}$ \\
Tal ris bawah (bottom line) & Poly Ethylene, panjang 45,31 m, diameter 2 mm, pilinan Z \\
Tal pemberat (sinker line) & Poly Ethylene, panjang 45, 31 m, diameter 2 mm, pilinan \\
& Z Plastik jerigen 5 liter, 2 buah. \\
Pelampung tanda & Batu, 5 kg, jumlah 2 buah. \\
Pemberat jangkar &
\end{tabular}

Sumber : Data Penelitian , 2017. 


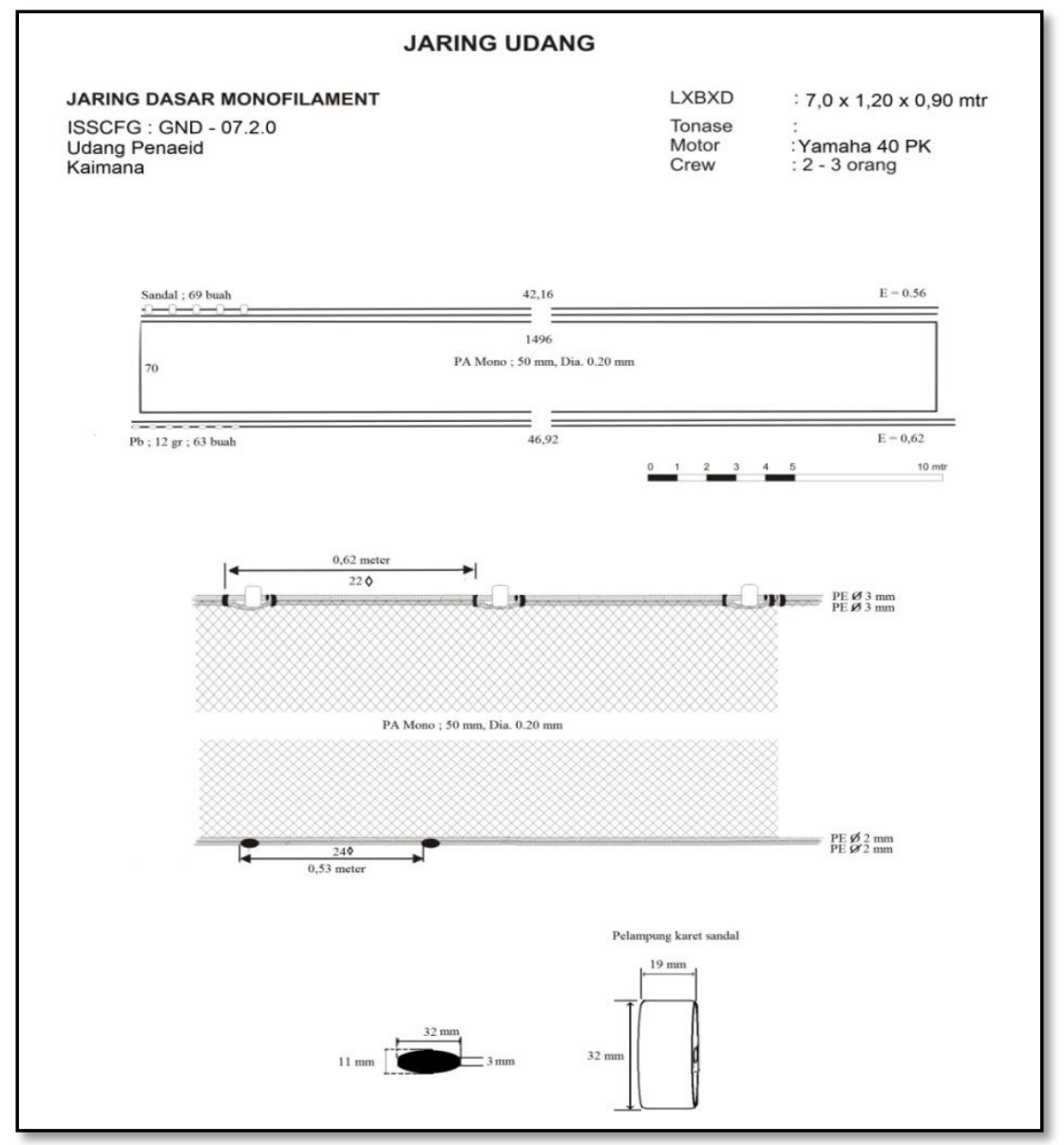

Gambar 3. Konstruksi Jaring udang PA monofilament di Kaimana

\section{Uji Efektivitas Jaring Ciker}

Uji coba pengoperasian jaring $P A$ Monofilament sistim aktif (ciker) dilakukan dengan tujuan untuk meningkatkan hasil tangkapan. Hal ini dilakukan sebagai upaya untuk meningkatkan nilai efektivitas dan efisiensi penangkapan. Pengoperasian sistim aktif hanya bisa dilakukan pada perairan khusus, yaitu pada perairan yang tidak terlalu dalam
(2-5 meter), dasar perairan relatif rata, tidak terdapat halangan berupa sampah atau tonggak kayu, serta substrat berupa pasir atau berlumpur. Uji coba ini dilakukan di Perairan Tawera, Kabupaten Kaimana menggunakan 2 unit jaring gillnet PA monofilament, setiap unit terdiri dari 4 piece, dengan ulangan sebanyak 9 kali ulangan. Hasil pengujian didapatkan data berikut ;
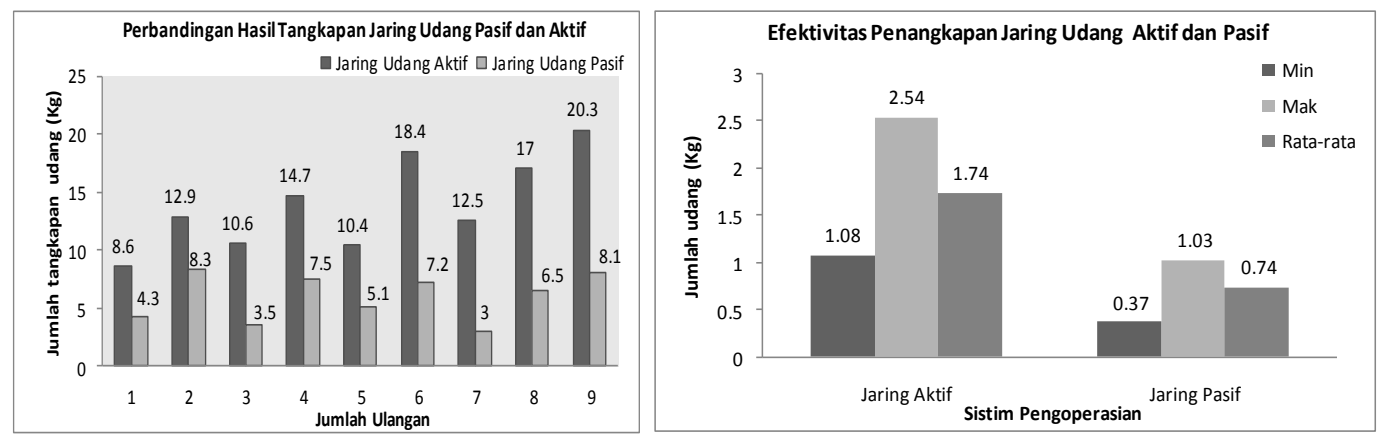

Gambar 4. Perbandingan Hasil tangkapan dan nilai efektivitas Jaring aktif dan Pasif

Gambar 4 menunjukkan bahwa hasil tangkapan udang pada pengoperasian aktif lebih banyak pada setiap ulangan dibandingkan dengan sistim pasif, dimana jaring aktif mampu menangkap udang sebanyak $125.41 \mathrm{~kg}$ (rata-rata $13.93 \mathrm{~kg}$ ) sedangkan jaring sistim pasif sebanyak $53.72 \mathrm{~kg}$ (rata-rata $5.96 \mathrm{~kg}$ ). Nilai efektivitas didapatkan dari output hasil tangkapan yaitu jumlah udang tertangkap dibandingkan dengan nilai target minimal nelayan. Berdasarkan hasil wawancara beberapa nelayan sekali melaut rata-rata mempunyai target minimal 810 kg dengan harga jual Rp.45.000,- sampai dengan 
Rp. 55.000,- sehingga digunakan output target minimal sebesar $8 \mathrm{~kg}$. Dengan asumsi sekali melaut memerlukan bbm sebanyak 20 liter dan ransum sekitar $50 \mathrm{rb}$, maka nelayan masih bisa mendapatkan hasil dengan target minimal Rp. 100.000,- sampai dengan Rp. 150.000,00.

Jaring ciker mendapatkan nilai rata-rata efektivitas 1.74 sedangkan jaring pasif sebesar 0.74 , sehingga jaring udang PA monofilament sistim aktif (ciker) memiliki efektivitas yang lebih tinggi dibandingkan dengan sistim pasif. Hasil ini sesuai dengan pengujian Kurniawan dkk (2017) dengan hasil ciker modifikasi mampu menangkap 3 kali lipat.

Hasil Uji $F$ menunjukkan bahwa nilai $F_{\text {hit }}\left(F_{\text {hit }}\right.$ =4) $>\mathrm{F}_{\mathrm{tab}}\left(\mathrm{F}_{(0.05 ; 8 ; 8)}=3.4\right)$ dan hasil Uji $\mathrm{t}$ juga menunjukkan bahwa nilai $\mathrm{t}_{\text {hit }}\left(\mathrm{t}_{\text {hit }}=5.39\right)>\mathrm{t}_{\mathrm{tab}}$ $\left(\mathrm{t}_{(0.05 ; 8)}=2.3\right)$ maka dapat disimpulkan bahwa kedua jenis alat tangkap menghasilkan hasil tangkapan udang yang berbeda nyata dan secara umum Jaring aktif lebih tinggi efektivitasnya dibandingkan dengan jaring pasif.

Sistim pengoperasian jaring secara aktif mendapatkan hasil tangkapan yang lebih efektif diduga dikarenakan jaring menyapu dasar perairan dan kolom perairan yang dilewati oleh jaring secara melawan arus sehingga memungkinkan udang lebih mudah tertangkap dibandingkan dengan cara menunggu udang untuk berenang dan tertangkap oleh jaring. Pada saat sapuan jaring, ada kemungkinan udang yang berada di dasar perairan akan terkejut dan melompat keluar dari lumpur sehingga terjerat oleh sapuan jaring, selain itu juga catcable area juga lebih luas karea sapuan jaring secara melingkar. Hal ini sesuai pendapat Rihmil dkk (2017) yang menyatakan bahwa jaring yang dioperasikan secara aktif dengan cara menyapu dasar perairan, diseret atau ditarik dengan pergerakan perahu melawan arus memiliki area sapuan yang lebih luas sehingga hasil tangkapannya lebih banyak dibandingkan dengan cara dihanyutkan.

\section{Hasil tangkapan sampingan (By-catch)}

By-catch merupakan ikan hasil tangkapan sampingan yang tidak dijadikan target tangkapan (Mardjudo, 2011). Hasil tangkapan sampingan pada alat tangkap adalah semua jenis biota laut yang ikut terjerat pada alat tangkap selain udang. Hasil tangkapan sampingan ini paling banyak adalah jenis ikan, dan sebagian kecil jenis kepiting. Meskipun sebagian by-catch sebagian dimanfaatkan oleh nelayan dengan cara dijual ataupun dikonsumsi, namun keberadaannya dianggap sangat mengganggu dan tidak diharapkan. Hal ini dikarenakan pelepasan by-catch cukup menyita waktu dan juga dapat merusak jaring.

By-catch selalu terdapat pada setiap pengoperasian jaring udang PA Monofilament. Hal ini dikarenakan alat tangkap menggunakan bahan PA monofilament dengan diameter benang yang sangat kecil yaitu $0.05 \mathrm{~mm}$, dan mesh size hanya 1,75 inch sehingga mempunyai daya jerat (entangled) cukup tinggi, selain itu juga terdapat banyak ikan yang bersimbiosis dengan udang sehingga ikut tertangkap (Rahantan dan Puspito, 2012). Spesies By-catch yang tertangkap pada jaring udang PA monofilament dapat diidentifikasi sebagai berikut.

Tabel 2. Jenis Ikan hasil tangkapan sampingan pada Jaring udang PA Monofilament

\begin{tabular}{|c|c|c|c|c|c|}
\hline \multirow[b]{2}{*}{ No } & \multirow[b]{2}{*}{ Jenis Ikan } & \multicolumn{2}{|c|}{ Jaring aktif (ciker) } & \multicolumn{2}{|c|}{ Jaring pasif } \\
\hline & & Jumlah (kg) & $\begin{array}{c}\text { Prosentase } \\
(\%)\end{array}$ & $\begin{array}{c}\text { Jumlah } \\
(\mathrm{kg})\end{array}$ & $\begin{array}{c}\text { Prosentase } \\
(\%)\end{array}$ \\
\hline 1 & Selanget (Anadontostoma $s p$ ) & 43.8 & 14.67 & 35.78 & 19.95 \\
\hline 2 & Hiu (Selachimorpha $s p)$ & 71.54 & 23.96 & 27.43 & 15.29 \\
\hline 3 & Manyung (Arius $s p$ ) & 37.79 & 12.66 & 24.45 & 13.63 \\
\hline 4 & Gulamah (Nibea sp) & 31.47 & 10.54 & 23.58 & 13.15 \\
\hline 5 & Kerong-kerong (Terapon sp) & 39.71 & 13.29 & 22.12 & 12.33 \\
\hline 6 & Beloso (Oxyeleotris $s p$ ) & 04.10 & 01.34 & 29.87 & 16.65 \\
\hline 7 & Kerapu (Epinephelus sp) & 00.50 & 0.17 & - & - \\
\hline 8 & Layur (Trichiurus sp) & 01.04 & 0.34 & - & - \\
\hline 9 & Kapas-kapas (Geres sp) & 02.11 & 0.71 & - & - \\
\hline 10 & Daun bambu (Scomberoides sp) & 06.80 & 02.28 & 10.71 & 0.39 \\
\hline 11 & Swanggi (Priacanthus sp) & 04.33 & 01.45 & - & - \\
\hline 12 & Kuro (Polydactylus sp) & 16.21 & 05.43 & 09.97 & 5.58 \\
\hline 13 & Petek (Leiognathus $s p$ ) & 29.98 & 10.04 & - & - \\
\hline 14 & Rajungan (Portunidae $s p$ ) & 02.95 & 0.99 & 01.91 & 01.08 \\
\hline 15 & Kepiting (Scylla $s p)$ & 06.35 & 02.13 & 02.33 & 01.29 \\
\hline 16 & Sebelah (Pleuronectiformes sp) & - & - & 01.2 & 0.67 \\
\hline & Jumlah & 298.57 & 100 & 179.41 & 100 \\
\hline
\end{tabular}

Sumber : Data Penelitian, 2017.

Jaring udang PA Monofilament lebih banyak dioperasikan pada perairan pantai yang dangkal (1- 5 meter), dekat dengan habitat mangrove yang masih berhubungan dengan pasang surut, sehingga mempunyai by-catch yang cukup bervariasi yaitu sebanyak 15 spesies. Tidak menutup kemungkinan jenis by-cath dapat berubah sesuai dengan waktu dan lokasi penangkapan. Foto hasil tangkapan sampingan (By-Catch) dapat dilihat pada Gambar 6 . 


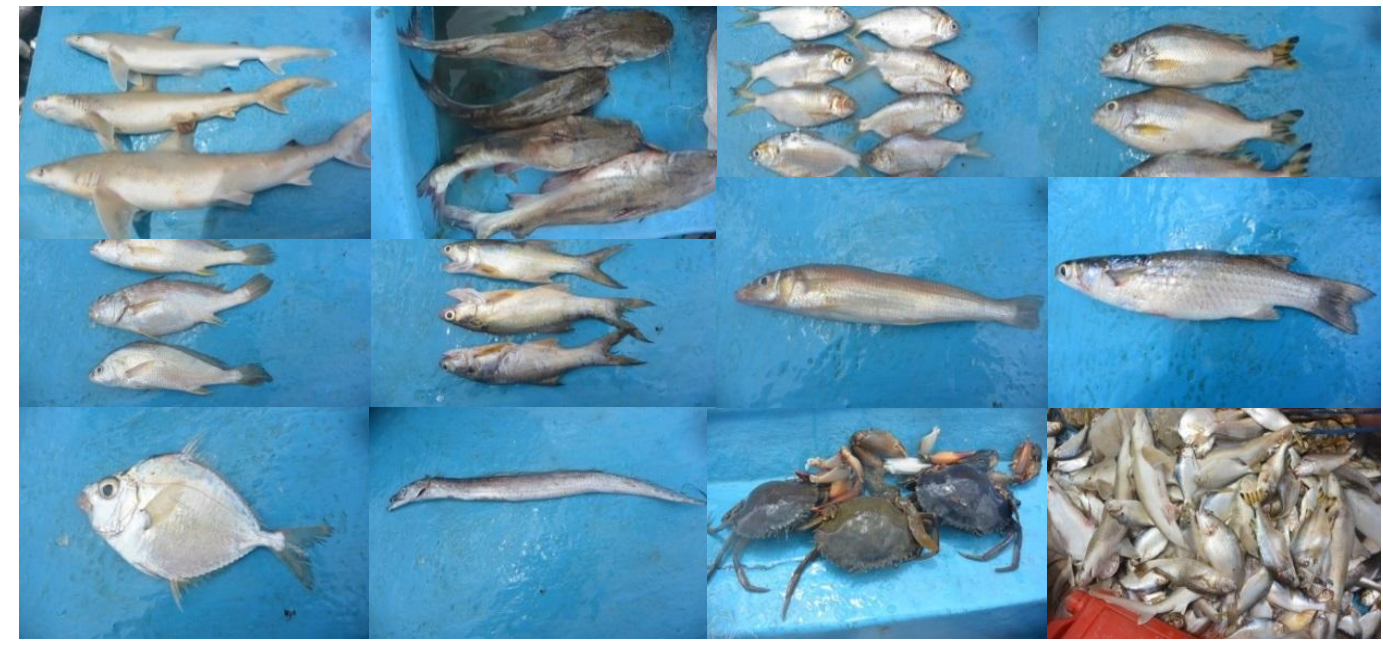

Gambar 5. Jenis By-Catch Jaring Udang PA Monofilament

\section{Uji Low Impact By-Catch}

Berdasarkan hasil pengujian, kedua perlakuan aktif dan pasif mempunyai by-catch yang sangat besar (high impact), yaitu lebih dari 50\% (Gambar
6). Data hasil tangkapan by-catch pada jaring aktif (ciker) selalu lebih banyak pada setiap ulangan, sehingga secara umum mempengaruhi nilai low impact by-catch, seperti Gambar 7 berikut.
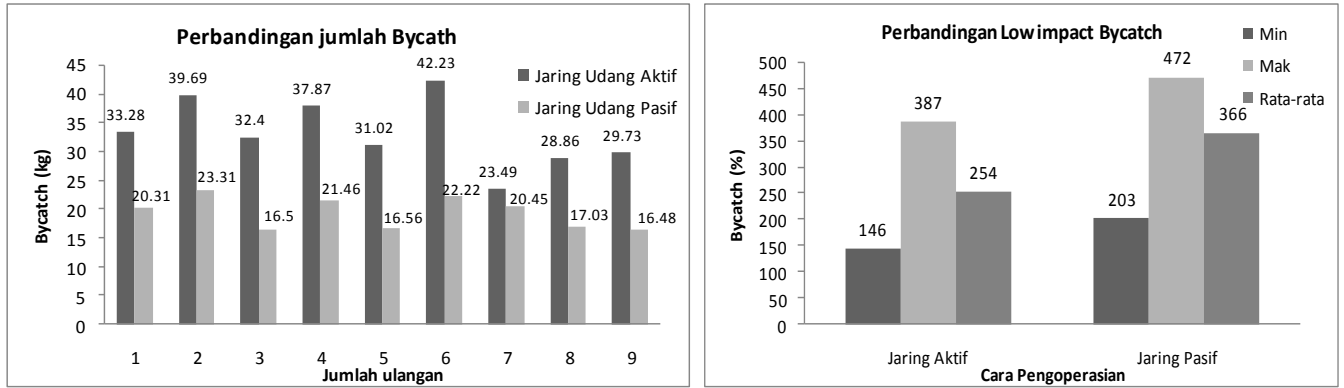

Gambar 6. Perbandingan jumlah by-catch dan low impact by-catch jaring aktif dan jaring pasif

Data hasil tangkapan by-catch selanjutnya dilakukan uji Kolmogorov Smirnov dan data menyebar normal, sehingga dilakukan uji Statistik parametrik yaitu Uji $\mathrm{F}$ atau Uji t. Hasil Uji $\mathrm{F}$ menunjukkan nilai $\mathrm{F}_{\text {hit }}\left(\mathrm{F}_{\text {hit }}=4.07\right)>\mathrm{F}_{\text {tab }}\left(\mathrm{F}_{(0.05 ; 8 ; 8)}=\right.$ 3.4) dan atau Uji t dengan nilai $t_{\text {hit }}\left(t_{\text {hit }}=4.35\right)>t_{\text {tab }}$ $\left(\mathrm{t}_{(0.05 ; 8)}=2.3\right)$ maka dapat disimpulkan bahwa kedua jenis alat tangkap menghasilkan by-catch yang berbeda nyata, dan jaring aktif atau sistim ciker ternyata mendapatkan by-catch yang lebih banyak dibandingkan jaring pasif.

Berdasarkan Gambar 6 (grafik) low impact bycatch pasif lebih besar nilainya dibandingkan dengan jaring pasif, hal ini dikarenakan jumlah by-catch yang tertangkap dibandingkan dengan hasil tangkapan jaring pasif yang nilainya lebih rendah sehingga terkesan mempunyai nilai by-catchnya lebih tinggi dibandingkan dengan jaring aktif. Akan tetapi jumlah by-catch (kg) secara keseluruhan lebih banyak didapatkan pada jaring aktif dan pada intinya kedua sistim pengoperasian mempunyai level high impact terhadap by-catch. Justru hal krusial yang sangat penting dan perlu mendapat perhatian adalah hasil tangkapan udang pada jaring ciker ternyata berbanding lurus dengan by-catch yang tertangkap, yaitu hasil tangkapan udang lebih banyak akan tetapi juga mendapatkan by-catch yang lebih banyak juga dibandingkan dengan jaring sistim pasif. Sementara program yang direkomendasikan untuk menangkap udang penaeid sebagai alternatif pengganti pukat udang adalah jaring sistim putar (ciker). Informasi yang didapatkan dari nelayan berdasarkan pengalaman bahwa by-catch akan lebih melimpah apabila menggunakan trammel net, sehingga nelayan lebih memilih menggunakan jaring udang gillnet $P A$ monofilament. Sementara itu, penelitian Kurniawan dkk (2017) menyatakan bahwa alat tangkap ciker belum dapat memberikan hasil tangkapan udang yang optimal, sehingga perlu dikembangkan kembali. Hanya saja Kurniawan dkk (2017) menfokuskan pada target hasil tangkapan utama yaitu udang dan tidak membahas by-catch, sehingga perlu dikembangkan penelitian lanjutan, selain untuk meningkatkan nilai efektivitas juga ditujukan untuk mengurangi by-catch. Harapannya tersedia alat alternatif untuk menangkap udang penaeid yang aplikatif dengan low impact rendah terhadap bycatch. Hal ini sesuai dengan rekomendasi (WWF, 2015), agar menciptakan alat alternatif untuk menangkap udang yang ramah lingkungan, meskipun 
pada saat ini masih direkomendasikan trammel net dan jaring klitik (gillnet monofilament).

\section{KESIMPULAN}

Berdasarkan riset awal ini maka dapat kami simpulkan bahwa "Pengoperasian jaring sistim aktif (ciker) mendapatkan hasil lebih banyak (lebih efektif) dibandingkan dengan jaring pasif, tetapi juga mendapatkan by-cath yang lebih tinggi".

\section{SARAN}

Hasil yang kami dapatkan di Kabupaten Kaimana merupakan bagian kecil dari gambaran penangkapan udang penaeid di Kaimana. Ini dikarenakan terbatasnya waktu penelitian yaitu hanya 9 kali ulangan dan dilakukan tidak pada musim puncak. Selain itu sistim pencatatan data di daerah dan informasi yang masih terbatas di lokasi penelitian, sehingga masih banyak yang perlu dilakukan penelitian lanjutan. Direkomendasikan untuk "Penelitian lanjutan redesain jaring ciker atau penelitian lainnya dalam penangkapan udang penaeid dengan tujuan utama mengurangi by-catch".

\section{DAFTAR PUSTAKA}

Astuti, E.,M. (2005). Dimensi Unit Penangkapan Pukat Udang dan tingkat Pemanfaatan Sumberdaya udang di Perairan Laut Arafura (Skripsi). Bogor : IPB.

Baran. (1999). A Review of Quantified relationships Between Mangrove and Coastal Resources. Phuket. Marine Biological Center, reseach Bulletin. 62: 57-64

Emmanuel, Babantunde E., Chukwu, Lucian O. (2010). Evaluating The Selective Peformances of Gill Net Used In Tropical Low Brackish Lagoon South-Western, Nigeria. Journal of American Science: 49-52

Fauziyah. (1997). Studi Tentang Efisiensi Teknik Unit Penangkapan Jaring Cucut (Liong Bun) di Cirebon [Skripsi]. Bogor: Institut Pertanian Bogor.

Iporenu HE., Aristi DP., Boesono, H. (2013). Analisis Perbandingan Hasil Tangkapan Bottom Set Gill Net Dengan Umpan Ikan Petek Segar dan Asin (Leiognathus Sp.) Di Perairan Jepara Jawa Tengah. Journal of Fisheries Resources Utilization Management and Technology. 2 (4) : 59-68.

Jhon, R.S. (1986). Manajement for produktivity. 2rd ed. England : John Willey and Son Press.

Kementerian Kelautan dan Perikanan (KKP). (2014). Peraturan Menteri Kelautan Dan Perikanan
Republik Indonesia Nomor 56/Permen$\mathrm{Kp} / 2014$. Penghentian Sementara (Moratorium) Perizinan Usaha Perikanan Tangkap Di Wilayah Pengelolaan Perikanan Negara Republik Indonesia. Jakarta : KKP.

Kementerian Kelautan dan Perikanan (KKP). (2015). Peraturan Menteri Kelautan dan Perikanan Republik Indonesia Nomor 2/PERMEN$\mathrm{KP} / 2015$. Larangan Penggunaan Alat Penangkapan Ikan Pukat Hela (Trawls) Dan Pukat Tarik (Seine Nets) Di Wilayah Pengelolaan Perikanan Negara Republik Indonesia. Jakarta : KKP.

Kurniawan, W., Riyanto A., Santoso, A.,E. (2017). Uji Operasional Alat Tangkap Ramah Lingkungan Jaring Ciker. Buletin Teknik Litkayasa. 15(1) : 47-55

Martasuganda, S. (2008). Jaring Insang (Gillnet). Edisi Revisi. Bogor : Institut Pertanian Bogor

Mardjudo, A. (2011). Analisis Hasil Tangkapan Sampingan (By-Catch) Dalam Perikanan Pukat Pantai Jenis Krakat Di Teluk Kota Palu Sulawesi Tengah. Jurnal KIAT Universitas Alkhairat. ISSN : 02116-7530

Misbah S, Razak A., Simau S., Gunaisah E., Ulath A., Sudirman, Handayani, Suruwaky A., Sepri, Muhsuryono, Mustasim, Muhfizar, Muhammad S,. (2017). Penangkapan Udang Penaeid Pasca Moratorium dan Pelarangan Kapal Trawl di Kabupaten Kaimana. Jurnal Airaha. 6 (2): 7080

Puspito, G. (2009). Perubahan Sifat-sifat Fisik Mata Jaringan Insang Hanyut Setelah Digunakan 5, 10, 15, dan 20 Tahun. Jurnal Penelitian Sains. 12 (3): 12-31

Rahantan, A., \& Puspito, G. (2012). Ukuran Mata Dan Shortening Yang Sesuai Untuk Jaring Insang Yang Dioperasikan Di Perairan Tual. Marine Fisheries. 3 (2) : 141-147.

Rihmi1, M.K., Puspito G., Wahju IR,. (2017). Modifikasi Konstruksi Trammel Net: Upaya Untuk Meningkatkan Hasil Tangkapan. Jurnal Teknologi Perikanan dan Kelautan 8(2): 169178

Suman, A \& Satria, F. (2014). Opsi Pengelolaan Sumberdaya Udang Di Laut Arafura (WPP 718). Jurnal Kebijakan Perikanan Indonesia. 6(2) : $97-104$

Sumiono, B. (2012). Status Sumberdaya Perikanan Udang Penaeid dan Alternatif Pengelolaannya di Indonesia. Jurnal Kebijakan Perikanan Indonesia. 4 (1): 27-34.

World Wide Fund for Nature (WWF). 2015. Perikanan Udang Penaeid, Panduan Penangkapan dan Penanganan. Jakarta: WWFIndonesia. 